\title{
Handleiding vir eksegete en ander studente van Klassieke en Nuwe-Testamentiese Grieks
}

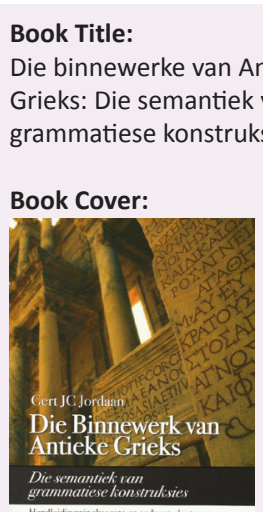

Author:

Gert Jordaan

ISBN:

978-0-86555-219-3

Publisher:

Potchefstroomse Teologiese Publikasies, Potchefstroom, 2014, R205.00*

*Book price at time of review

Review Title:

Handleiding vir eksegete en ander studente van Klassieke en Nuwe-Testamentiese Grieks

Reviewer:

Pierre Jordaan ${ }^{1}$

\section{Affiliation:}

${ }^{1}$ School of Ancient Language and Text Studies, North-West University, South Africa

Email:

pierre.jordaan@nwu.ac.za

Postal address:

PO Box 19510, Noordbrug

2522, South Africa

How to cite this book review: Jordaan, P., 2014,

'Handleiding vir eksegete en ander studente van Klassieke en Nuwe-Testamentiese Grieks', In die Skriflig 48(1), Art. \#1867, 2 pages. http:// dx.doi.org/10.4102/ids. v48i1.1867

Read online:

Scan this QR
code with your
smart phone or
mobile device
to read online.

In 'n tydperk waarin die onderrig van Grieks enersyds deur verskeie kweekskole van tradisionele kerke afgeskaal word en andersyds deur die gebruik van elektroniese hulpmiddels vervlak word, verskyn hierdie boek van G.J.C. Jordaan, professor in die Nuwe Testament aan die Fakulteit Teologie, Noord-Wes Universiteit.

Die binnewerk van Antieke Grieks (verkorte titel) word deur Jordaan as 'n naslaanboek vir filoloë en eksegete (agterblad) beskou. Dit is nogal 'n gewigtige aanspraak wat Jordaan maak, hoewel dit nie ongegrond is nie. Hierdie boek is inderdaad ' $n$ bewys van uitnemende vakmanskap en die toepassing van kennis op 'n baie hoë vlak. 'n Verdere pluspunt van hierdie boek, wat ook as 'n intermediêre of gevorderde grammatikahandboek getipeer kan word, is die feit dat dit, sover my kennis strek, 'n eerste in Afrikaans is. Die alombekende Grieks met Begrip (1995) was slegs 'n inleidende grammatikahandboek.

Die Binnewerk van Antieke Grieks bestaan uit twee afdelings. Die eerste afdeling (hfst. 1-5) handel oor werkwoorde. Die tweede afdeling (hfst. 6-10) handel oor naamwoorde. Verder is daar nog drie bylaes oor styl wat die gebruike van OU en $\mathrm{MH}$, stylfigure en laastens die individuele styl van Nuwe-Testamentiese skrywers insluit. Die boek is netjies afgerond met 'n literatuurlys, saakregister, afkortingslys van Nuwe-Testamentiese boeke sowel as 'n Nuwe-Testamentiese teksregister. Die fokus van die publikasie is egter op klassieke sowel as Nuwe-Testamentiese Grieks.

Jordaan se uitgebreide kennis van die Griekse taalkunde is in sy volledige besprekings van die vakinhoud sigbaar. Hy bespreek verskeie elementêre aspekte wat in geen ander grammatikahandboek vir beginners voorkom nie, maar wat belangrik is vir die interpretasie van die teks. 'n Voorbeeld daarvan is die dominansie van persoon (bl. 4-5).

Jordaan pak die boek op 'n tipiese wyse aan: vanaf die eenvoudige na die ingewikkelde. Hy verduidelik eers die eenvoudige, byvoorbeeld die handelsaard en -stadium van die indikatiewe werkwoorde (bl. 6-7). Daarna behandel hy bogenoemde twee sake uitvoerig met voorbeelde. Dit was insiggewend om onder andere weer die ingressiewe, konatiewe, iteratiewe en gnomiese aard van die verskillende werkwoorde te sien (bl. 6-15). Hoofstuk 3 handel oor die betekenis van die verskillende modi. Die opsommende gebruike van modi deur middel van tabelle op bladsy 16, 20, 25 en 28 vergemaklik die verstaan van die verskillende tipes modi. Hoofstuk 4 handel oor die betekenis van verbale naamwoorde en adjektiewe. Die gebruike van die infinitief in hoofsinne as bevel, infinitivus absolutus en uitroep (bl. 33) is nie die gewone gebruike nie, maar ook hieraan gee Jordaan die nodige aandag. Verder behandel hoofstuk 4 ook die byvoeglike en bywoordelike deelwoorde synde verbale naamwoorde. Menige student sal baat vind by hierdie klassifikasies. Hoofstuk 5 behandel die betekenis van tye buite die indikatief. Hieronder sorteer die konjunktief, optatief, infinitief en imperatief. Die onderskeid wat Jordaan tussen handelstadium en handelsaard tref, maak die verklarings weereens makliker.

In die tweede afdeling, vanaf hoofstuk 6, kom die behandeling van werkwoorde aan die beurt. Die tabelle op bladsye 56, 58 en 63 verskaf weereens 'n goeie opsomming van die hele hoofstuk. Hoofstuk 7 (die konstruksie van hoofsinne) handel oor sinne wat sekerhede, moontlikhede, aannames, wense, vrae en uitroepe uitdruk. Op bladsy 78 behandel Jordaan die eerste keer retoriese vrae met die belofte van 'n latere uitvoeriger bespreking daarvan.

Hoofstuk 8 handel oor die konstruksie van saamgestelde sinne. Hierdie aspek word gewoonlik deur studente as 'moeilik' of 'uiters gekompliseerd' beskou. Jordaan slaag egter daarin om die spreekwoordelike 'angel' daaruit te haal. Die sinopsis op bladsy 105 gee 'n goeie samevatting van die hoofstuk. 
In hoofstuk 9 word naamvalle en naamwoorde uitvoerig behandel en in hoofstuk 10 word die koppeling van voorsetselfrases met sekere naamvalle uiteengesit. Hoofstuk 11 handel oor bywoordelike en byvoeglike bepalings.

'n Verder pluspunt van die boek is die verdere drie bylaes oor styl. Bylae 2 bevat stylfigure in die Nuwe Testament en klassieke tekste. Daarna bespreek Jordaan 27 stylfigure. Die feit dat hy nie net die stylfiguur noem nie, maar ook 'n definisie en die effek daarvan gee, dra baie tot die verstaanbaarheid van die hoofstuk by. Ek het die bespreking van casus pendens en chiasme (bl. 168-169) asook sy siening oor retoriese vrae (bl. 173) baie leersaam gevind. Bylae 3 handel oor die individuele styl van sekere NuweTestamentiese skrywers.

Ek kon geen beredenerings- of argumentatiewe foute in die boek vind nie. Hierdie boek van G.J.C. Jordaan kan dus met groot vrymoedigheid aanbeveel word as ' $n$ intermediêre of gevorderde Griekse grammatikahandboek. Op die manier sal nie net die kennis van die ernstige student verdiep nie, maar daar word ook aan 'n uitmuntende Griekskenner erkenning gegee. 